poszczególnych rozdziałów. Książka zawiera wyczerpującą bibliografię, w większości niestety anglojęzyczną, oraz dokładne indeksy przedmiotowe i cytowanych źródeł. Przez najbliższe dziesięciolecia praca ta stanowić będzie bez wątpienia lekturę obowiązkową dla tych wszystkich, którzy będą się zajmować relacjami pomiędzy chrześcijaństwem a judaizmem w II wieku.

ks. Leszek Misiarczyk - Plock

\title{
David ROKÉAH, Justin Martyr and the Jews, Leiden - Boston - Köln 2002, Brill, ss. 157.
}

Prezentowane poniżej studium, choć w wersji anglojęzycznej ukazuje się dopiero teraz, jest jednak tłumaczeniem uzupełnionej wersji dzieła autora z języka hebrajskiego, wydanej już w 1998 roku przez wydawnictwo Uniwersytetu Hebrajskiego w Jerozolimie. Praca jest niewielka objętościowo (134 strony tekstu) i została pomyślana, jak to zresztą zaznacza w przedmowie sam Autor, jako wprowadzenie do thumaczenia na język hebrajski Dialogu Justyna, które właśnie przygotowuje. Znajdują się w niej więc również refleksje przedstawione już wcześniej w innych artykułach tego samego Autora, a dotyczące chrześcijańskich korzeni antysemityzmu, tematu tyleż modnego, co mało precyzyjnego. Autor więc zaraz w przedmowie definiuje wybranie Izraela, obecne zarówno w Biblii Hebrajskiej i literaturze rabinicznej, jak też w Nowym Testamencie, zwłaszcza w Ewangeliach synoptycznych, jako oparte na trzech zasadniczych faktorach: wybór Abrahama i jego potomków, powierzenie Izraelowi Tory, i niższość pogan. Zdaniem autora, św. Paweł starał się odrzucić te prawdy, przenosząc ideę boskiego wybrania z Żydów na chrześcijan. Justyn rozwinąłby tę argumentacją Pawłową, koncentrując swój Dialog właśnie na owych trzech kluczowych tematach: Abraham i jego potomkowie, wartość Tory i status pogan. W ten sposób Justyn wypełniłby plan św. Pawła, gdyż obydwaj głosili, że poganie są spadkobiercami obietnic udzielonych przez Boga Abrahamowi, podczas gdy Żydzi zostaliby odrzuceni i wydziedziczeni, ponieważ nie uwierzyli w Jezusa jako Mesjasza. W konsekwencji więc, wedhug Autora, współczesny dialog chrześcijańsko-żydowski nie będzie niczym więcej, niż swego rodzaju ,grupową terapią” dopóty, dopóki chrześcijanie nie odrzucą Listów Pawłowych jako źródła swej inspiracji. Komuś może wydawać się dziwne, że tyle miejsca poświęcam przedmowie autora, ale sądzę, iż jest ona kluczowa do zrozumienia reszty książki.

Praca składa się ze wstępu, zresztą bardzo zdawkowego (3,5 strony), i dziesięciu tematycznych rozdziałów. Rozdziały I-V to zasadniczo powtórka znanych już od dawna badaczom Dialogu Justyna i szeroko dyskutowanych kwestii. A więc najpierw: chronologia życia Justyna i datacja Dialogu (rozdz. I), 
w czym jednak nie znajdujemy nic nowego. Rozdział II poświęcony jest kwestiom adresatów i kontekstu historycznego dzieła Justyna, zwłaszcza judaizmu II wieku, gdzie Autor korzysta w sposób dosyć arbitralny z artykułu M. Macha (Justin Martyr's Dialogus cum Tryphone Iudaeo and the development of Christian anti-judaism, w: O. Limor - G.G. Stroumsa (ed.), Contra Iudaeos: ancient and medieval polemics between Christians and Jews, Tübingen 1996, 27-47) wybierając $z$ niego to, co mu służy do uzasadnienia jego własnej tezy. Mach jest bowiem zdania, że do połowy II wieku dyskusja dotycząca tożsamości chrześcijaństwa i jego relacja do judaizmu była wewnętrznym problemem chrześcijaństwa i niewielki wpływ na nią miało nauczanie zarówno samego Jezusa jak też Pawła. Autor nie zgadza się z taką argumentacją, przekonując o wpływie św. Pawla na List do Hebrajczyków, a Jezusa na Ewangelię św. Jana oraz inne Ewangelie. Świadczyłby o tym również atak na chrześcijaństwo niektórych rabinów z początku II wicku oraz słynne Birkhat Ha-Minim. Nasz Autor zgadza się natomiast, że Dialog jest tekstem dotyczącym raczej problemów wewnątrzchrześcijańskich i nie był wcale adresowany do Żydów. Jego zdaniem, Justyn nie znał judaizmu rabinicznego epoki, a podobieństwa z literaturą rabiniczną, zaproponowane przez Golfahna, nie są rzeczywiste, lecz stanowią naturalną interpretację tekstów biblijnych. Hipoteza ta jest jednak dyskusyjna. Znajdziemy bowiem w Dialog $u$ wiele tradycji wspólnych z tradycjami rabinicznymi epoki, które $z$ pewnością nie są naturalną interpretacją tekstu biblijnego. Dobrym przykładem może być tutaj Dial. 40, 4 gdzie Justyn przytacza tradycję rabiniczną, potwierdzoną przez traktat Miszny Yoma 6, 1 o tym, by dwa kozły na Yom Kippur były jednakowe. Tego typu nakaz nie znajduje się jednak w Starym Testamencie, więc nie może to być żadna wspólna naturalna interpretacja tekstu biblijnego.

W rozdziale III Autor zastanawia się nad ewentualną znajomością przez Justyna języka hebrajskiego konkludując, iż wszystko wskazuje na to, że go nie znał. Sama kwestia jest na tyle akademicka, że nadaje się rzeczywiście tylko na wstęp do Dialogu, a nie na rozdział monografii. Również IV rozdział nie wnosi nic nowego do naszej wiedzy o dziele Justyna. Autor przytacza w nim opinie za zależnością Justyna od pism Filona Aleksandryjskiego (Goodenough) oraz jej przeciwników (Chadwick, Bernard, Skarsaune), by wreszcie pójść za opinią Skarsaune, który doszukiwał się źródeł egzegezy Justyna w literaturze judeochrześcijańskiej. Bardziej dyskusyjny jest natomiast rozdział V niniejszej pracy. Autor za większością badaczy przyjmuje zależność Dialogu od Septuaginty, Nowego Testamentu oraz pism judeo-chrześcijańskich czy też chrześcijańskiej interpretacji tekstów żydowskich, jak np. Testamentów Dwunastu Patriarchów, natomiast odrzuca jakikolwiek związek pomiędzy pismem Justyna a tradycją rabiniczną. Argumenty jego nie są jednak przekonujące, gdyż wielu badaczy zarówno chrześcijańskich (Williams, Shotwell), jak też żydowskich (Goldfahn), od dawana opowiada się za takim związkiem. Ostatnio powrócił do tej tematyki 
M. Hirshmann (Polemic Literary Units in the Classical Midrashim and Justin Dialogue with Trypho, „Jewish Quarterly Review” 83:1993, 369-384), który w tradycji o wężu miedzianym, krwi baranka paschalnego i podniesieniu rąk przez Mojżesza podczas walki z Amalekitami Mekhilty dostrzega, zresztą zupełnie słusznie, elementy polemiki antychrześcijańskiej.

Najciekawsze są, bez wątpienia, rozdziały VI-X prezentowanej tutaj rozprawy. I tak, w rozdziale VI Autor przedstawia zależność Justyna od Pawłowej argumentacji na temat Prawa Mojżeszowego, które wraz z przyjściem JezusaMesjasza straciło swoją moc wiążącą dla Jego uczniów. Dostępują oni bowiem usprawiedliwienia, podobnie jak Abraham, na podstawie wiary, a nie obrzezania (Abraham został usprawiedliwiony przed obrzezaniem), albo przestrzegania Prawa Mojżeszowego (Abel, Noe i Melchizedek dostąpili usprawiedliwienia długo przed pojawieniem się Prawa Mojżeszowego). Autor dopatruje się w tym punkcie wpływu Marcjona na refleksję Justyna, w co osobiście wątpię, gdyż bardzo trudno będzie ją wykazać. Nie każdy argument Justyna przeciw Prawu Mojżesza pochodzi od Marcjona, albo też jest przejawem jego antysemickiej postawy. Podobnie nie przekonuje argumentacja Autora o tym, ze to właśnie $\mathrm{w}$ celu przeciwstawienia się tendencjom gnostyckim, Justyn wyjaśnia czasowość Prawa i fakt nadania go Żydom. Myślę, że to z powodu dyskusji wewnątrzchrześcijańskiej, animowanej zwłaszcza przez chrześcijan pochodzenia żydowskiego, Justyn stara się odróżnić czasowo ważne przepisy Starego Testamentu dotyczące ofiar, które miały za cel ustrzec Żydów przed idolatrią, od choćby Dekalogu, zachowującego nadal swą wartość również dla chrześcijan. Wypada się natomiast zgodzić z Autorem co do faktu, że interpretacja obrzezania przez Justyna jako znaku umożliwiającego rozpoznanie i ukaranie Żydów po Powstaniu Bar Kochby, jest wyraźnie uzależniona od kontekstu historycznego. Rozdzial VII stara się zrekonstruować refleksję Pawła i Justyna nad statusem Żydów i pogan po przyjściu Mesjasza. Podczas gdy Paweł zdaje się jeszcze widzieć Żydów jako naród wybrany i synów Abrahama, Justyn radykalizuje swoje wnioski podkreślając, iż są oni pozbawieni zarówno Bożego wybraństwa, jak też wydziedziczeni z obietnic Abrahama. W rozdziale VIII Autor stara się natomiast pokazać, że postawa Pawla na temat zachowywania Prawa Mojżeszowego i wobec pogan, znacznie odbiega od postawy samego Jezusa w tych dwóch dziedzinach. Wniosek dosyć ryzykowny i oparty bardziej na analizie historycznej niż teologicznej. Gdyby bowiem pozostali apostołowie dostrzegali, że Paweł fałszuje nauczanie Jezusa, i sam chce być tak naprawdę założycielem nowego chrześcijaństwa oderwanego od judaizmu, jak chce Autor, na pewno bardzo szybko by zareagowali, nie potwierdzając jego nauki na Soborze Jerozolimskim. Do ciekawego natomiast wniosku dochodzi Autor w rozdziale IX na temat Henocha, Noego i Melchizedeka: podczas gdy są oni wysławiani w literaturze żydowskiej przedchrześcijańskiej, to w literaturze rabinicznej pochrześcijańskiej są bardzo mocno kry- 
tykowani. Zmiana została prawdopodobnie spowodowana wykorzystywaniem tych postaci przez autora Listu do Hebrajczyków i Justyna jako przykładu osób usprawiedliwionych przed pojawieniem się Prawa Mojżeszowego. Wreszcie w rozdziale X Autor analizuje odpowiedzi rabinów na propagowanie wiary chrześcijańskiej, zwlaszcza słynne Birkhat Ha-Minim, które miało właśnie na celu zneutralizować wpływ chrześcijańskich misjonarzy na wspólnoty żydowskie. Wcześniejsi rabini nie zajmują się jeszcze tą tematyką, ponieważ chrześcijanie pochodzenia żydowskiego początkowo nie kwestionowali Bożego wybraństwa Izraela. Proces ten rozpoczyna się wraz z przyjęciem Pawłowej wersji chrześcijaństwa, jako odłączonego od judaizmu, i napływem chrześcijan pochodzenia pogańskiego.

Tyle prezentacji samej książki i wniosków Autora. Warto dodać, że jest ona bardzo pięknie wydana w prestiżowym wydawnictwie Brill, które już od wielu lat słynie z publikacji dobrych opracowań z dziedziny Judaica. Książka zawiera dokładne indeksy osobowe i rzeczowe. Zakończę natomiast trzema uwagami krytycznymi.

Po pierwsze więc, niektóre części prezentowanego studium zostały pomyślane, jak to zaznaczyłem wyżej, jako wprowadzenie do tłumaczenia na język hebrajski Dialogu Justyna, stąd też nie wnoszą nic albo bardzo mało do dyskusji nad nim. Możnaby się nawet zastanawiać, czy w ogóle elementy tak oczywiste powinny być publikowane w pracy monograficznej. Po drugie, Autor, moim zdaniem, źle sytuuje centralny temat Dialogu. Nie jest nim dla Justyna argumentacja negatywna przeciw Torze, czy wykluczenie Żydów $z$ dziedzictwa Abrahama (Abraham i jego potomkowie, wartość Tory i status pogan), lecz chrystologia, czyli rozumienie tajemnicy pojawienia się Mesjasza, Syna Bożego i konsekwencje wynikające $\mathrm{z}$ tego faktu dla Żydów i pogan. Krytyka Tory, podkreślanie jej czasowego charakteru oraz kwestia dziedzictwa Abrahama są niejako wprowadzeniem do centralnego tematu: Jezus jest obiecanym Mesjaszem, kto w Niego wierzy, staje się dziedzicem wiary Abrahama, niezależnie od narodowości. Po trzecie wreszcie, Autor, podobnie jak wielu innych zajmujących się tematyką relacji pomiędzy chrześcijaństwem a judaizmem antycznym, pozostaje w jakimś sensie niewolnikiem myślenia, które w każdej krytyce judaizmu czy Żydów dopatruje się antysemityzmu. Kategoria ta jednak, rozumiana jako nienawiść rasowa, jest nieaplikowalna do pierwszych wieków chrześcijaństwa, gdzie można mówić raczej o anty-judaizmie o podłożu religijnym, a nie rasowym. Optyka zaś interpretacji tekstów wczesnochrześcijańskich w kluczu antysemickim bywa myląca, bo wypacza myśl autora tekstów i łatwo może prowadzić do interpretacji ideologicznej. 